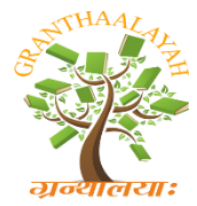

\author{
INTERNATIONAL JOURNAL OF RESEARCH - \\ GRANTHAALAYAH \\ A knowledge Repository
}

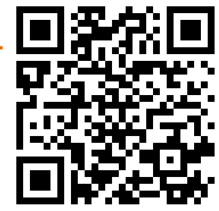

Social

\title{
ASSESSMENT ON THE EFFECTIVENESS OF THE ALGORITHM APPROACH IN TEACHING PHYSICS
}

\author{
Norrie E. Gayeta ${ }^{* 1}$ \\ ${ }^{1}$ College of Teacher Education, Batangas State University, Batangas City, 4200, Philippines
}

\begin{abstract}
The need to implement more vigorously new approaches in teaching and learning has become a necessity for education. It is essential to use new teaching approaches and strategies such that creating knowledge and developing skills will not only be easier but also more meaningful to students. One of the new approaches nowadays in the field of science is the algorithm approach. Thus, this study assesses the effectiveness of the algorithm approach in teaching Physics. The descriptive type of research was used with the questionnaire as the main instrument in gathering data. Respondents of the study were 42 science teachers from Batangas National High School for the school year 2017-2018. The statistical tool used in the study was weighted mean. The study revealed that algorithm approach was effective in teaching physics particularly in encouraging independent learning in problem solving, making students solve physics problems more easily, and arousing students' curiosity.
\end{abstract}

Keywords: Algorithm Approach; Effectiveness of Instruction; Teaching Physics.

Cite This Article: Norrie E. Gayeta. (2019). "ASSESSMENT ON THE EFFECTIVENESS OF THE ALGORITHM APPROACH IN TEACHING PHYSICS." International Journal of Research - Granthaalayah, 7(6), 72-76. https://doi.org/10.29121/granthaalayah.v7.i6.2019.752.

\section{Introduction}

Studies have revealed that students achieve a higher level of performance and display more interest in the class and in the subject matter under the hands of highly competent teachers. Teachers, therefore, must have the required competencies with regards to teaching in order to meet the demands and standards of quality education. They must be knowledgeable and skilful in selecting and using relevant and effective teaching approaches and strategies. Their responsibility is to make sure that students learn what they need to learn.

According to Romando [1], the teachers' duty in modern day classroom is to stimulate students to become independent and self-propelled learners. This calls for students' motivation to process information and to comply with a given task. It implies a systematic strategy for teachers to design daily activities that could drive students to work by themselves. Moreover, as explained by Javier [2], strategies and approaches are vehicles for the teacher to achieve long ranged lesson objectives 
such as those set for a grade level across subject areas. The more closely the teaching approaches match the preferred learning styles of the students, the more effective learning will be.

Lucan and Corpuz [3] cited that the teaching of physics is an important concern in science education. The aims in teaching physics are to develop understanding of its concepts and key principles, its processes, skills and desirable values which will make students scientifically literate, productive and effective citizens. It requires the teacher to provide students collaborative learning communities. Therefore, teachers must be ready to initiate instructional innovations to meet the needs of their students [4].

Science teaching, teaching physics in particular, can be very rewarding through the use of varied creative problem solving strategies. Problem-solving is a major part of a science course especially in physics. It is true that physics and problem solving are inseparable. It is, therefore, very important to develop the skills in analyzing and interpreting the problem. If the teachers are equipped with the necessary knowledge and skills in teaching the concepts meaningfully and creatively, then students could appreciate the usefulness of physics lessons in their day-to-day life.

According to Masangcay [5], poor academic achievement in physics may be attributed to many factors, one of which is the teachers' strategy. Problem solving skills are important to be developed during the learning of physics. The study of Cruzat [6] revealed that one fairly common difficulty experienced by the students with physics problems is inability to connect the abstract or conceptual aspects of physics with reality. Understanding the basics of the subject is the key to problem solving. He added that being innovative in terms of coming up with new strategies in teaching address the different learning styles of students.

Algorithm is one of the problem-solving approaches that may help the students to understand more easily how to solve a problem. In this approach, there is a defined set of step by step procedures that provides the correct answer to a particular problem. Such step by step approaches can be useful in teaching situations where each decision must be made following the same process and where accuracy is critical because the process follows a prescribed procedure. It involves critical thinking, creativity and finding out the solutions by complete self-activity. If the method is implemented effectively, the students learn to formulate good questions, identify conclusions and evaluate the worth and importance of those conclusions [7].

Towards this end, all teachers must have the knowledge and skills in the selection and use of effective teaching approaches and strategies that could cater to the needs of the 21 st century learners. With this conviction, the researcher was inspired and challenged to pursue this study on assessing the effectiveness of algorithm approach in teaching physics among the junior high school students of Batangas National High School with the hope of enhancing the teaching and learning process in science, particularly in physics. Moreover, the researcher believes that results of the study will strengthen the use of aforementioned approach in teaching physics.

\section{Research Methods}

The descriptive type of research was used in this study with the questionnaire as the main instrument in gathering data. Respondents of the study were 42 science teachers from Grade 7 to 
10 of Batangas National High School for the school year 2017-2018. In order to gather the needed data, a letter of request was sent to the school principal and department head of science of Batangas National High School to seek permission to conduct the study. The statistical tool used in the study was weighted mean. Instrument used was evaluated, validated, administered, tallied and scored according to the accepted practices in research. Interview was also conducted to science teachers to substantiate the findings of the study. The data were submitted to the statistician for treatment after which the data are analyzed and interpreted.

\section{Results and Discussions}

Effectiveness is one factor that needs to be considered by the teacher in choosing an approach. How this approach affects the students' performance must always be given consideration. Table 1 presents the assessment of teachers on the effectiveness of algorithm approach in teaching physics.

Table 1: Effectiveness of Algorithm Approach in Teaching Physics

\begin{tabular}{|l|l|l|}
\hline Items & $\begin{array}{l}\text { Weighted } \\
\text { Mean }\end{array}$ & $\begin{array}{l}\text { Verbal } \\
\text { Interpretation }\end{array}$ \\
\hline $\begin{array}{l}\text { Encourage independent learning in problem solving and } \\
\text { concepts among students in physics }\end{array}$ & 3.00 & Effective \\
\hline Make students solve physics problem easier & 3.00 & Effective \\
\hline Arouse students' curiosity & 2.98 & Effective \\
\hline $\begin{array}{l}\text { Develop students' value of responsibility on their own } \\
\text { learning }\end{array}$ & 2.93 & Effective \\
\hline $\begin{array}{l}\text { Enhance students' ability and skills needed in hands-on } \\
\text { activities }\end{array}$ & 2.93 & Effective \\
\hline $\begin{array}{l}\text { Build up students' point of view towards the topics in } \\
\text { physics }\end{array}$ & 2.90 & Effective \\
\hline Establish a lively classroom environment & 2.90 & Effective \\
\hline Enhance students' creative and critical thinking & 2.90 & Effective \\
\hline $\begin{array}{l}\text { Allow the students to determine their own strengths and } \\
\text { weaknesses in problem solving }\end{array}$ & 2.86 & Effective \\
\hline Composite Mean & $\mathbf{2 . 9 2}$ & Effective \\
\hline
\end{tabular}

It can be noted from the table that the highest weighted mean of 3.00 was obtained by two indicators of effectiveness of the algorithm approach, namely, encouraging independent learning in problem solving and concepts among students in physics, and making students solve physics problems easier. Result implies that algorithm approach provides room for students to work independently in solving complex problems because it enables students to be analytical thinkers. With the development of analytical thinking, they are able to compare, contrast, evaluate, synthesize, and apply their analyses in answering difficult questions or in solving problems in real time independently without instruction or supervision. In addition, it helps them solve problems more easily since this approach provides students time to explain and try out some problem solving strategies, and even model their thinking as they work with difficult math problems.

It is also contained in the table that algorithm approach was effective in arousing students' curiosity with a weighted mean of 2.98. Curiosity of students can affect how they answer the different 
problems given to them. This is what Valerott [8] meant by saying that the attention and the curiosity of students are important in the process of learning. He also stated that problem solving is intended to develop independent learning particularly in the choice of strategies that students use to facilitate solving problems.

The effectiveness of algorithm approach in developing students' value of responsibility on their own learning, and in enhancing students' ability and skills needed in the hands-on activity got the same weighted mean of 2.93. Result implies that this approach makes students more independent in managing their own learning. Likewise, this approach promotes student-centered activities or the hands-on and minds-on learning process. This conforms to the study of Reyes [9] which showed how hands-on experiences made the students think and express their own ideas. Therefore, the algorithm approach is important in teaching science especially physics since it requires many opportunities for demonstrations. It allows the students to engage in real-life situations for them to understand the lessons more clearly and acquire knowledge and skills more efficiently.

The table also reveals that algorithm approach was effective in building up students' point of view towards the topic in physics, establishing a lively classroom environment, and enhancing students' creative and critical thinking, all garnering the same weighted mean of 2.90. Results indicate that this approach enabled the students to entertain different ideas about the topic being studied, express themselves freely, use their critical and creative thinking skills in solving mathematical and logical problems and in the process they developed into creative and critical thinkers who are interested in gaining new knowledge and skills. These outcomes could be attained because algorithm approach promotes interactive problem solving activities that develop the thinking skills of students. This encouraging development of students conforms to the idea of Schwartz [10] in which problem solving includes the development of thinking skills, enabling them to participate actively in class activities.

It can also be gleaned from the table that algorithm approach is effective allowing the students to determine their own strengths and weaknesses in problem solving. This got the lowest weighted mean of 2.86. From the interview conducted teachers revealed that it may be because they usually applied algorithm approach is groups or in pairs. This findings is in contrast with Doyle's [11] concept that teaching science especially physics promotes the development of learning in solving problem on their own.

Composite mean of 2.92 shows that algorithm approach was effective in teaching physics.

\section{Conclusion}

Algorithm approach was effective in encouraging independent learning in problem solving, making students solve physics problems more easily, and in arousing students' curiosity.

\section{References}

[1] Romando, R. (2007). Student Motivation. Ezine Articles

[2] Javier, M., (2012). A System Approach to Teaching Strategies for Today’s Classroom. Manila. Philippines:REX Publication 
[3] Lucan, H. and Corpuz, J., (2007). Learning Styles and Factors Affecting the Students. International Journal of Academic Project.

[4] Delgado, M. H., (2013). Proposed Motivation Strategies and Intervention Activities in Physics. Unpublished Master's Thesis, Batangas State University, Batangas City.

[5] Masangcay, D., (2015). Teaching and Learning of Physics. Manila, Philippines:REX Publication.

[6] Cruzat, D. (2008). Critical Thinking Skills and Academic Performance in Physics of Fourth Year High School Students in Sta. Teresa College. Unpublished Master's Thesis.Batangas State University, Batangas City.

[7] Almossawi, M., (2017). Algorithm as step-by-step procedure. Retrieved from http://shodhganga.inflibnet.ac.in/bitstream/10603/144397/5/05_algorithim.pdf

[8] Valerott, C., (2007). Becoming a Middle Level Teacher.London: Edinburgh University Press.

[9] Reyes, L., (2008). Designing Teaching Strategies. International Journal of Academic Project.

[10] Schwartz, M., (2008). The Effectiveness of Problem Solving. New York: Penguin Random House.

[11] Doyle, T., (2004). New Faculty of Professional Development: Planning an Ideal Program. Stillwater, UK: New Forums Press.

\footnotetext{
*Corresponding author.

E-mail address: norrie_junegayeta@ yahoo.com.ph
} 